\title{
Comparison of Immunocytologic Localization of Insulin- Like Growth Factor Binding Protein-4 in Normal and Polycystic Ovary Syndrome Human Ovaries
}

\author{
XINJIAN PENG, TAKeshi MARUO, TAKashi SAMOTO, AND Matsuto MOCHIZUKI \\ Department of Obstetrics and Gynecology, Kobe University School of Medicine, Kobe 650, Japan
}

\begin{abstract}
The cytologic localization and cellular levels of insulin-like growth factor binding protein-4 (IGFBP-4) in follicular and stromal compartments of normal and polycystic ovary syndrome (PCOS) ovaries during follicular growth and regression were investigated by the avidin/biotin immunoperoxidase method with a polyclonal antibody to human IGFBP-4, and a comparative assessment of IGFBP-4 expression in normal and PCOS ovaries was provided. In normal human ovaries, IGFBP-4 was immunolocalized to the oocyte throughout follicular growth, while the surrounding granulosa and theca cells were negligible for IGFBP-4 immunostaining in primordial, preantral and antral follicles. IGFBP-4 immunostaining became apparent, however, in the lutein cells of corpora lutea and the granulosa and theca cells of atretic follicles. In PCOS ovaries, prominent immunostaining for IGFBP-4 was apparent not only in the oocyte, but also in the surrounding granulosa cells in preantral follicles. In antral follicles from PCOS women without hyperinsulinemia, IGFBP-4 immunostaining was more prominent in the granulosa cells than the theca cells, whereas in antral follicles from PCOS women with hyperinsulinemia IGFBP-4 immunostaining was more prominent in the theca cells than the granulosa cells. Furthermore, in atretic follicles within PCOS ovaries IGFBP-4 immunostaining was prominent in the theca cells, regardless of the association of hyperinsulinemia. These results demonstrate for the first time that there is a great difference in cellular expression of IGFBP-4 between normal and PCOS human ovaries. In light of the high affinity of IGFBP-4 for IGF-I, the abundant expression of IGFBP-4 in granulosa and theca cells of preantral and antral follicles of PCOS ovaries may lead to decreases in the bioavailability of IGF-I in those follicles. The decrease in IGF-I-mediated stimulation of gonadotropin actions on granulosa and theca cells in preantral and antral follicles may impair the induction of aromatase activity, causing an androgenic microenvironment which is characteristic of atretic follicles and PCOS follicles.
\end{abstract}

Key words: IGFBP-4, Human ovary, PCOS, Hyperinsulinemia, Immunohistochemistry, Atresia

(Endocrine Journal 43: 269-278, 1996)

THE OVARY has been shown to be a site of insulin-like growth factor (IGF) production and action [1]. IGF-I is a potent stimulator of granulosa cell proliferation and differentiation in synergy with gonadotropins [1-4]. It is therefore thought that

Received: September 22, 1995

Accepted: January 18, 1996

Correspondence to: Dr. Takeshi MARUO, Department of Obstetrics and Gynecology, Kobe University School of Medicine, 7-5-1 Kusunoki-cho, Chuo-ku, Kobe 650, Japan
IGF-I plays an important role in the selection of the preovulatory follicle by amplifying the action of gonadotropins. These actions of IGF-I are mediated through the specific receptors and can be modified by specific carrier or binding proteins to which IGFs are bound. In body fluids, the majority of IGFs do not exist as free polypeptides, but are bound to a family of binding proteins. To date, six IGF-binding proteins (IGFBPs) have been identified, cloned and characterized, and enumerated as IGFBP-1, - 2, -3, -4, -5 and -6 in the order in 
which they were discovered [1, 5, 6]. Although each IGFBP has a different amino acid sequence and presumably a different set of physiological functions, the precise functions of the IGFBPs remain unclear. Depending on the target tissues, these IGFBPs are capable of either inhibiting or enhancing the actions of the IGFs [7-11]. The IGFBPs can therefore be considered to play a critical role in modifying the biological actions of IGFs. In the ovary, only inhibitory actions of IGFBPs on follicular function have been demonstrated to date [12-16], Exogenously administered IGFBP-2 and -3 were reported to inhibit FSH-stimulated estradiol and progesterone production in cultured rat granulosa cells [12]. In the rat ovary, the mRNAs for IGFBP-2, IGFBP-3 and IGFBP-4 were shown to be selectively expressed in the interstial cells, copora lutea and granulosa cells of atretic follicles, respectively $[17,18]$.

As IGF-I synergizes with follicular stimulating hormone (FSH) to stimulate follicular maturation, it seems that IGFBP modification of IGF action may play a role during follicular growth or loss to atresia. During the follicular phase of the cycle, only a limited number of follicles are recruited to ovulate, whereas the vast majority of follicles never ovulate, but become atretic at different stages of follicular development. The process of atresia is an all or none phenomenon in that an entire follicle undergoes atresia or continues along the development pathway. Recent studies have demonstrated that apoptotic cell death is associated with follicular atresia [19]. Under normal condition, women produce a single dominant follicle that participates in a single ovulation in each cycle. This event occurs as a result of two interrelated processes: recruitment and selection.

Polycystic ovary syndrome (PCOS) is a heterogenous disorder in which chronic anovulation is a common feature despite the presence of many small microcystic antral follicles. In PCOS ovaries, the initial step in folliculogenesis, namely recruitment and growth to the small antral stage, seems intact, but the following step, selection of a dominant preovulatory follicle, does not occur, leading to an accumulation of a large number of small antral follicles. Furthermore, in PCOS women insulin resistence is common [20-22], and the association of varying degrees of hyperandrogenism and hyperinsulinemia is often seen [23, 24]. The mechanism responsible for the arrest of folliculogenesis in
PCOS ovaries has not been elucidated. Recently, in this context, several laboratories have reported that IGFBP-4 in the sheep as well as IGFBP-4 mRNA expression in the rat were increased in the atretic vs. nonatretic follicles $[17,25]$ and that IGFBP-2 and IGFBP-4 were present in greater amounts in follicular fluid (FF) aspirated from atretic follicles in normal cycling women or PCOS follicles than in mature follicles [26-28]. These findings suggest that IGFBP-4 appears to be correlated with atresia in the rat, sheep, and human, but we are not aware of any previous reports which discribed cellular distribution of IGFBP-4 in the human ovary during follicular growth, regression and atresia.

Thus, in the present study, cytologic localization of IGFBP-4 in follicular and stromal compartments of the normal human ovaries during follicular growth and regression was investigated and a comparative assessment of IGFBP-4 expression in normal and PCOS ovaries was provided.

\section{Materials and Methods}

\section{Tissue preparation}

Ovarian tissues were obtained from 12 women with regular menstrual cycles who underwent abdominal hysterectomy with uni- or bilateral salpingo-oophorectomy for a variety of gynecological conditions including leiomyoma, endometriosis and early cervical neoplasia. The collection of these tissues has been approved by the Institutional Review Board. These patients ranged in age from 32 to 41 years old with a mean age of 36 years. PCOS ovarian tissues were obtained from four patients with a clinical diagnosis of PCOS undergoing wedge resection of the ovaries. The clinical diagnosis of PCOS was made on the basis of the presence of amenorrhea, increased $\mathrm{LH}$ with a $\mathrm{LH} /$ FSH ratio of $>3$, and a varying degree of hyperandrogenism, and confirmed in the ovarian specimens obtained by wedge resections of the ovaries. Clinical and endocrine profiles of the four PCOS patients are summarized in Table 1. Data presented in Table 1 meet the criteria for the clinical diagnosis of PCOS. Informed consent was obtained from each patient for the use of ovarian tissues for immunohistochemical studies. The stage of the menstrual cycle was determined from the last re- 
Table 1. Laboratory data for four patients with a clinical diagnosis of PCOS

\begin{tabular}{ccccccccc}
\hline Patient no. & $\begin{array}{c}\text { Age } \\
(\mathrm{yr})\end{array}$ & $\begin{array}{c}\mathrm{LH} \\
(\mathrm{IU} / \mathrm{L})\end{array}$ & $\begin{array}{c}\text { FSH } \\
(\mathrm{IU} / \mathrm{L})\end{array}$ & LH-FSH & $\begin{array}{c}\mathrm{E} 1 \\
(\mathrm{ng} / \mathrm{L})\end{array}$ & $\begin{array}{c}\mathrm{E} 2 \\
(\mathrm{ng} / \mathrm{L})\end{array}$ & $\begin{array}{c}\mathrm{T} \\
(\mu \mathrm{g} / \mathrm{L})\end{array}$ & $\begin{array}{c}\text { Insulin } \\
(\mathrm{mU} / \mathrm{L})\end{array}$ \\
\hline 1 & 21 & 42 & 11 & 3.8 & 145 & 51 & 3.2 & 59 \\
2 & 29 & 31 & 7.2 & 4.3 & 62 & 31 & 1.9 & 46 \\
3 & 22 & 39.3 & 8 & 4.9 & 44 & 35 & 1.1 & 14 \\
4 & 20 & 47 & 11 & 4.3 & 158 & 37 & 1.1 & 13 \\
\hline
\end{tabular}

corded menstrual period. Ovaries were graded into six categories: early follicular, midfollicular, late follicular, early luteal, midluteal and late luteal phases of the menstrual cycle. On histological examination, individual follicles were categorized as primordial, preantral, antral or preovulatory and atretic follicles. Of the 12 normal cycling women included in this study, 4 had corpora lutea. The ovarian tissues obtained were fixed in $4 \%$ buffered neutral formalin, dehydrated and embedded in paraffin. Sections $4 \mu \mathrm{m}$ thick were deparaffinized and examined by standard histological techniques.

\section{Immunohistochemical staining}

Immunohistochemical staining was performed by the avidin/biotin immunoperoxidase method with a polyvalent immunoperoxidase kit (Omnitags, Lipshaw, Michigan) as previously described by Maruo and Mochizuki [29]. A rabbit polyclonal antibody to human IGFBP-4 (Austral Biologicals, California) was used as the primary antibody in this study. This antibody recognizes human IGFBP-4 with a minor cross reactivity only with IGFBP-2. In order to abolish the cross reactivity with IGFBP-2, the primary antibody $(1.0 \mathrm{mg} / \mathrm{ml})$ was preincubated with human recombinant IGFBP2 (Austral Biologicals, BBP-350-2) at a ratio of $1 \mu \mathrm{g}$ of IgG antibody to $1 \mu \mathrm{g}$ of human recombinant IGFBP-2 and then diluted 1:50 before use. The sections were counterstained with Harris' hematoxylin and mounted with glycerine phosphate buffer solution.

To assure the specificity of the immunological reactions, adjacent control sections were subjected to the same immunoperoxidase method, with the exception that the primary antibody to IGFBP-4 was replaced by nonimmune rabbit IgG (Immunon, Industry Drive, Pittsburgh) at the same dilution as the specific antibody. In the abovementioned controls, no positive staining was observed. Furthermore, preabsorption of the primary antibody with human IGFBP-4 (Austral Biologicals, California) at a ratio of $1 \mu \mathrm{g}$ of $\operatorname{IgG}$ of antibody to $1 \mu \mathrm{g}$ of human IGFBP-4 resulted in complete abolishment of the positive immunostaining. Furthermore, in order to determine whether individual follicles were healthy or atretic, adjacent sections were subjected to immunohistochemical staining of proliferating cell nuclear antigen (PCNA) with a monoclonal antibody to PCNA (Signet Lab, Inc., Massachusetts). PCNA immunostaining in the nuclei of granulosa cells was abundant in healthy antral follicles, but least abundant in atretic antral follicles.

The intensity of immunostaining was evaluated by repeated staining of the same specimens and by more than two observers. It was graded as $(-)$ for no immunostaining, $(+)$ for weak but definitely detectable immunostaining, $(++)$ for moderate immunostaining and $(+++)$ for intense immunostaining.

\section{Results}

Immunolocalization of IGFBP-4 in the normal human ovaries at different stages of follicular growth is given in Table 2. In primordial follicles during the early follicular phase, IGFBP- 4 was immunolocalized only to the oocyte, whereas the surrounding flattened pregranulosa cells were negative for IGFBP-4 immunostaining (Fig. 1). In preantral follicles during the early follicular phase (Fig. 2) and antral follicles during the late follicular phase (Fig. 3A), the oocyte showed immunolocalization of IGFBP-4, while the surrounding granulosa cells, theca cells and stromal cells were negligible for IGFBP-4 immunostaining. Preabsorption of the IGFBP-4 antibody with human IGFBP-4 resulted in the abolishment of positive immunostaining in the oocyte (Fig. 3B), 
Table 2. Immunostaining for IGFBP-4 in the normal human ovaries at different stages of follicular development

\begin{tabular}{lcccc}
\hline Follicular stage & Oocyte & Granulosa cells & Theca cells & stromal cells \\
\hline Primordial $(\mathrm{n}=10)$ & + & - & - & - \\
Preantral $(\mathrm{n}=6)$ & + & - & - & - \\
Antral $(\mathrm{n}=4)$ & + & - & ++ & - \\
Atretic $(\mathrm{n}=4)$ & & ++ & & Stromal cells \\
\hline Luteal phase & Lutein cells & - \\
\hline Corpus luteum $(\mathrm{n}=4)$ & & ++ & - \\
Corpus albican $(\mathrm{n}=8)$ & - &
\end{tabular}

The $n$ represents the number of follicles examined.

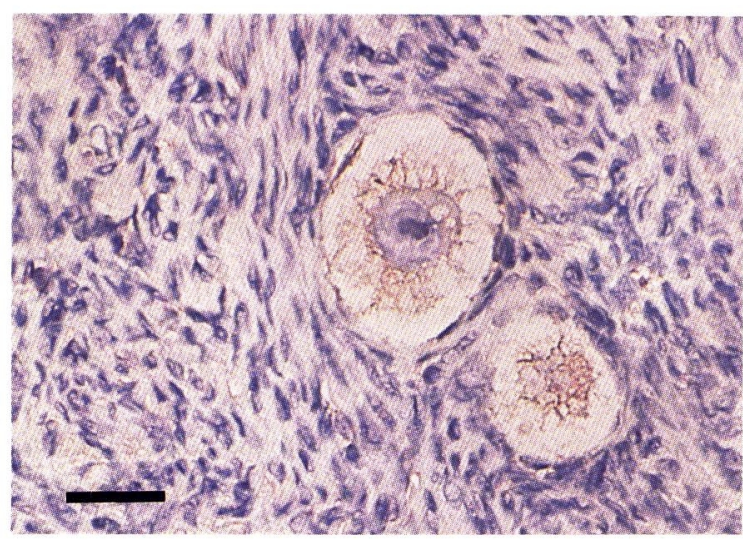

Fig. 1. Immunohistochemical localization of IGFBP-4 in primordial follicles of normal human ovary. IGFBP4 was immunolocalized only to the oocyte. Bar represents $10 \mu \mathrm{m}$. Original magnification, $\times 400$.

but in corpora lutea during the midluteal phase, IGFBP-4 immunostaining became apparent in the granulosa lutein and theca lutein cells (Fig. 4A). Corpora albicans were negative for IGFBP-4 immunostaining (Fig. 4B). On the other hand, in atretic follicles during the early follicular phase, IGFBP-4 immunostaining was prominent in the granulosa and theca cells (Fig. 5).

Immunolocalization of IGFBP-4 in PCOS ovaries at different stages of follicular development is given in Table 3. In primordial follicles within PCOS ovaries during the early follicular phase, IGFBP-4 was immunolocalized only to the oocyte, regardless of the presence or absence of the association with hyperinsulinemia (Fig. 6). In preantral follicles within PCOS ovaries during the early follicular phase, IGFBP-4 immunostaining became apparent not only in the oocyte but also in the

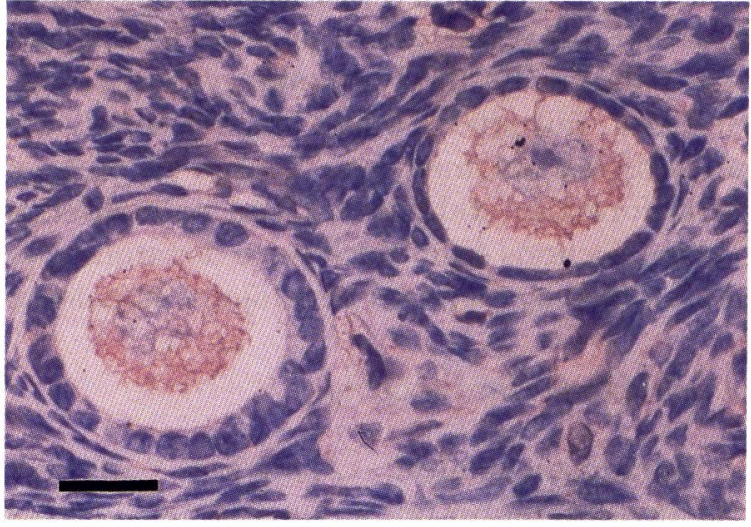

Fig. 2. Immunohistochemical localization of IGFBP-4 in preantral follicles of normal human ovary. Immunostaining for IGFBP-4 was localized to the oocyte, whereas the surrounding granulosa cells were negative for IGFBP-4 immunostaining. Bar represents $10 \mu \mathrm{m}$. Original magnification, $\times 400$.

surrounding granulosa cells (Fig. 7). The presence or absence of the association of hyperinsulinemia did not affect the pattern of IGFBP-4 immunostaining in the preantral follicles, but in antral follicles within PCOS ovaries the presence or absence of the association of hyperinsulinemia greatly affected the pattern of IGFBP-4 immunostaining. In antral follicles from PCOS women without hyperinsulinemia during the early follicular phase, IGFBP-4 immunostaining was more prominent in the granulosa cells relative to that in the theca cells (Fig. 8A), whereas in antral follicles from PCOS women with hyperinsulinemia during the early follicular phase, IGFBP-4 immunostaining was more prominent in the theca cells relative to that in the granulosa cells (Fig. 8B). On the other hand, in atretic follicles within PCOS ovaries during the 

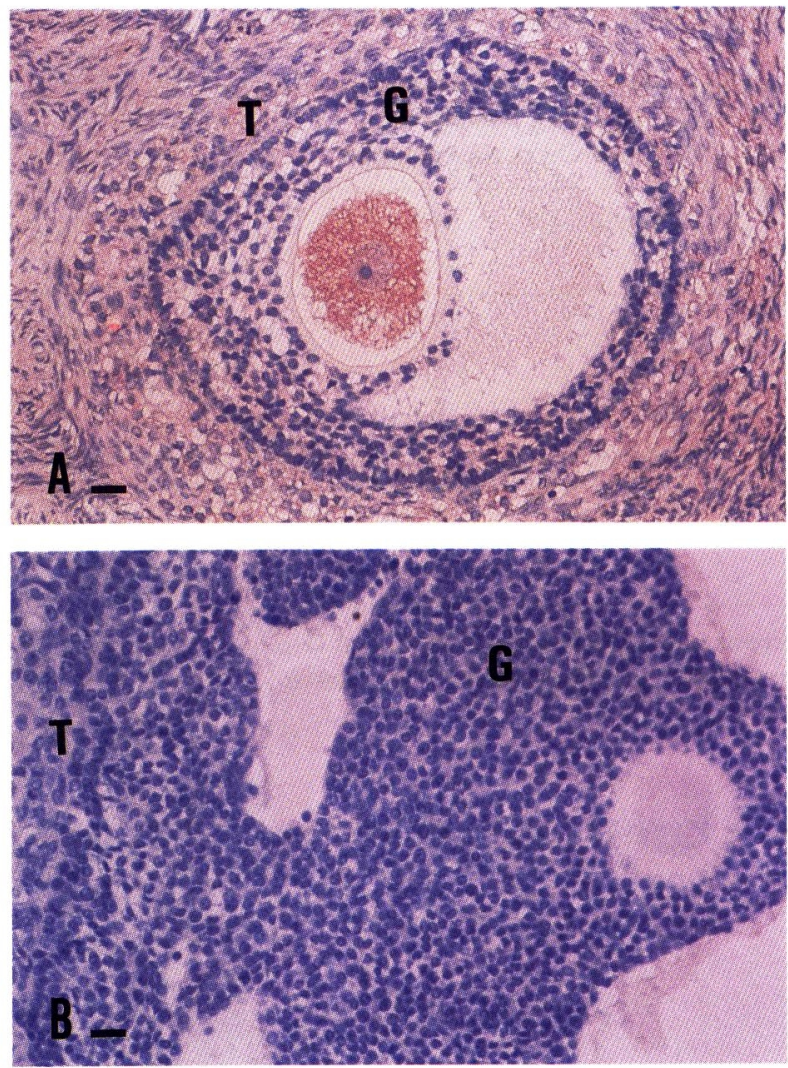

Fig. 3. Immunohistochemical localization of IGFBP-4 in antral follicles of normal ovary (A). Immunostaining for IGFBP-4 was negligible in the granulosa and theca cells. Preabsorption of the primary antibody with human IGFBP-4 showed a lack of positive immunostaining of the oocyte (B). G, granulosa; $\mathrm{T}$, theca. Bar represents $10 \mu \mathrm{m}$. Original magnification, $\times 200$.

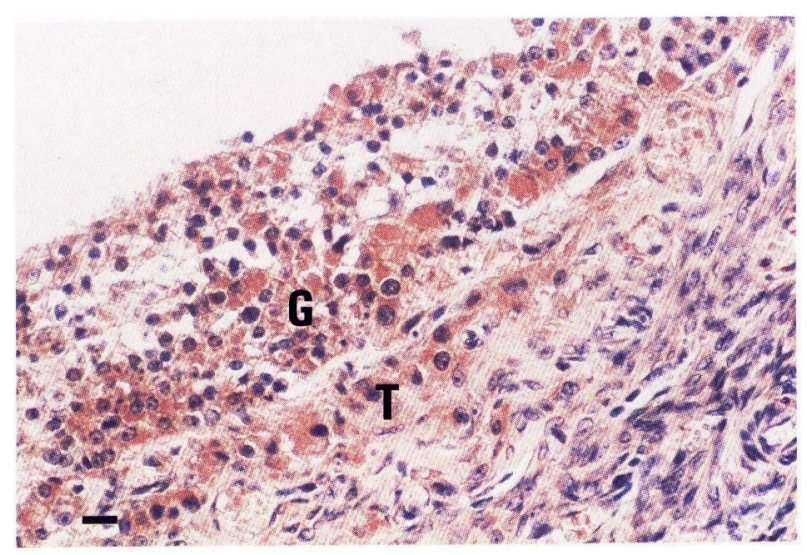

Fig. 5. Immunohistochemical localization of IGFBP-4 in atretic follicles of normal ovary. The granulosa and theca cells in atretic follicles showed prominent immunostaining for IGFBP-4. G, granulosa; T, theca. Bar represents $10 \mu \mathrm{m}$. Original magnification, $\times 200$.
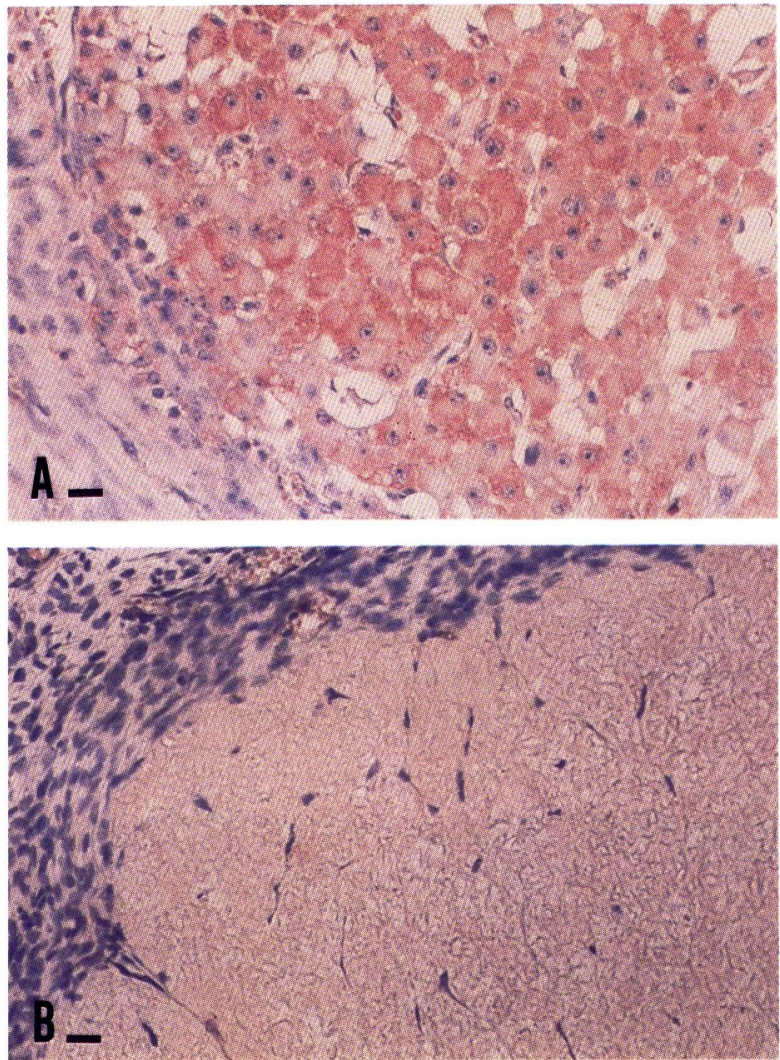

Fig. 4. Immunohistochemical localization of IGFBP-4 in the corpus luteum (A) and corpus albicans (B). Granulosa lutein cells of the corpus luteum showed positive immunostaining for IGFBP-4, whereas the corpus albicans was negative for IGFBP-4 immunostaining. Bar represents $10 \mu \mathrm{m}$. Original magnification, $\times 200$.

early follicular phase, IGFBP-4 immunostaining was prominent in the theca cells, regardless of the presence or absence of the association of hyperinsulinemia (Fig. 9).

\section{Discussion}

The present study demonstrates for the first time that there is a great difference between normal and PCOS human ovaries in the immunohistochemically detected cellular expression of IGFBP-4. At the primordial stage of follicle development in both normal and PCOS ovaries, IGFBP-4 was only localized to the oocyte. The expression of IGFBP-4 in the oocyte persisted in the preantral and antral stage of follicle development. Since we have ob- 
Table 3. Immunostaining for IGFBP-4 in PCOS ovaries at different stages of follicular development

\begin{tabular}{|c|c|c|c|c|c|c|c|c|}
\hline \multirow[b]{2}{*}{$\begin{array}{l}\text { Follicular } \\
\text { stage }\end{array}$} & \multicolumn{4}{|c|}{$\begin{array}{l}\text { PCOS subjects } \\
\text { without hyperinsulinemia }\end{array}$} & \multicolumn{4}{|c|}{$\begin{array}{c}\text { PCOS subjects } \\
\text { with hyperinsulinemia }\end{array}$} \\
\hline & Oocyte & GC & $\mathrm{TC}$ & $\mathrm{SC}$ & Oocyte & GC & $\mathrm{TC}$ & $\mathrm{SC}$ \\
\hline $\begin{array}{l}\text { Primordial } \\
(\mathrm{n}=12)\end{array}$ & + & - & & - & + & - & & - \\
\hline $\begin{array}{l}\text { Preantral } \\
(n=10)\end{array}$ & + & ++ & + & - & + & ++ & + & - \\
\hline $\begin{array}{l}\text { Antral } \\
(n=15)\end{array}$ & + & ++ & - & - & + & - & ++ & - \\
\hline $\begin{array}{l}\text { Atretic } \\
(n=12)\end{array}$ & & - & ++ & - & & - & ++ & - \\
\hline
\end{tabular}

The ovarian tissue specimens were obtained from two PCOS subjects with and two without hyperinsulinemia (see Table 1). GC, granulosa cell; TC, theca cell; SC, stromal cell. $\mathrm{n}$ is the number of follicles examined.
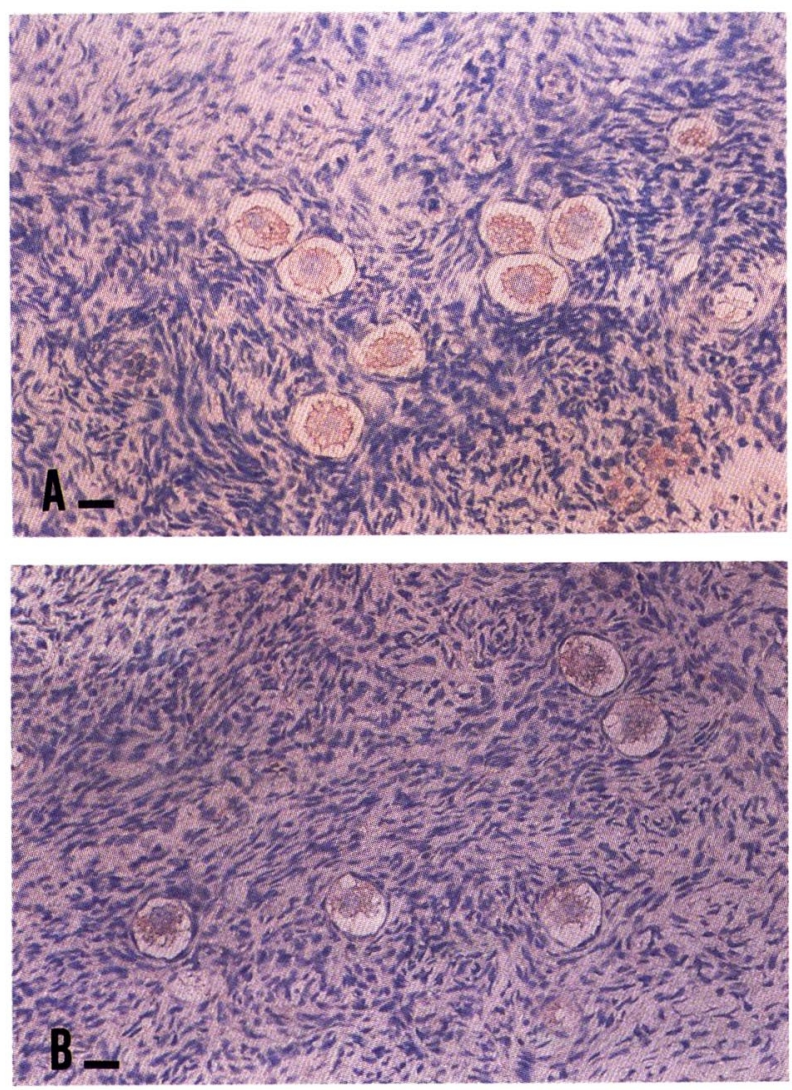

Fig. 6. Immunohistochemical localization of IGFBP-4 in primordial follicles from a PCOS patient without hyperinsulinemia (A) and from a PCOS patient with hyperinsulinemia (B). Immunostaining for IGFBP-4 was localized to the oocyte. Bar represents $10 \mu \mathrm{m}$. Original magnification. $\times 200$.
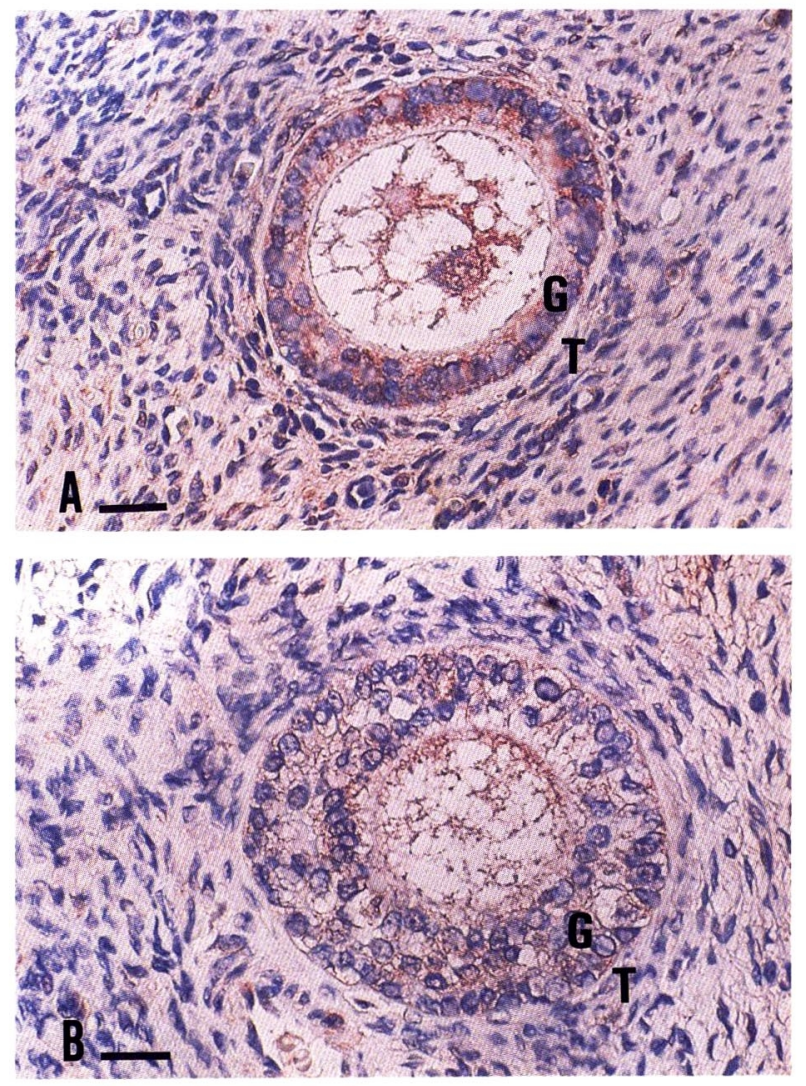

Fig. 7. Immunohistochemical localization of IGFBP-4 in preantral follicles from a PCOS patient without hyperinsulinemia (A) and from a PCOS patient with hyperinsulinemia (B). Immunostaining for IGFBP-4 became apparent not only in the oocyte but also in the surrounding granulosa cells. $G$, granulosa; $T$, theca. Bar represents $10 \mu \mathrm{m}$. Original magnification. $\times 400$. 

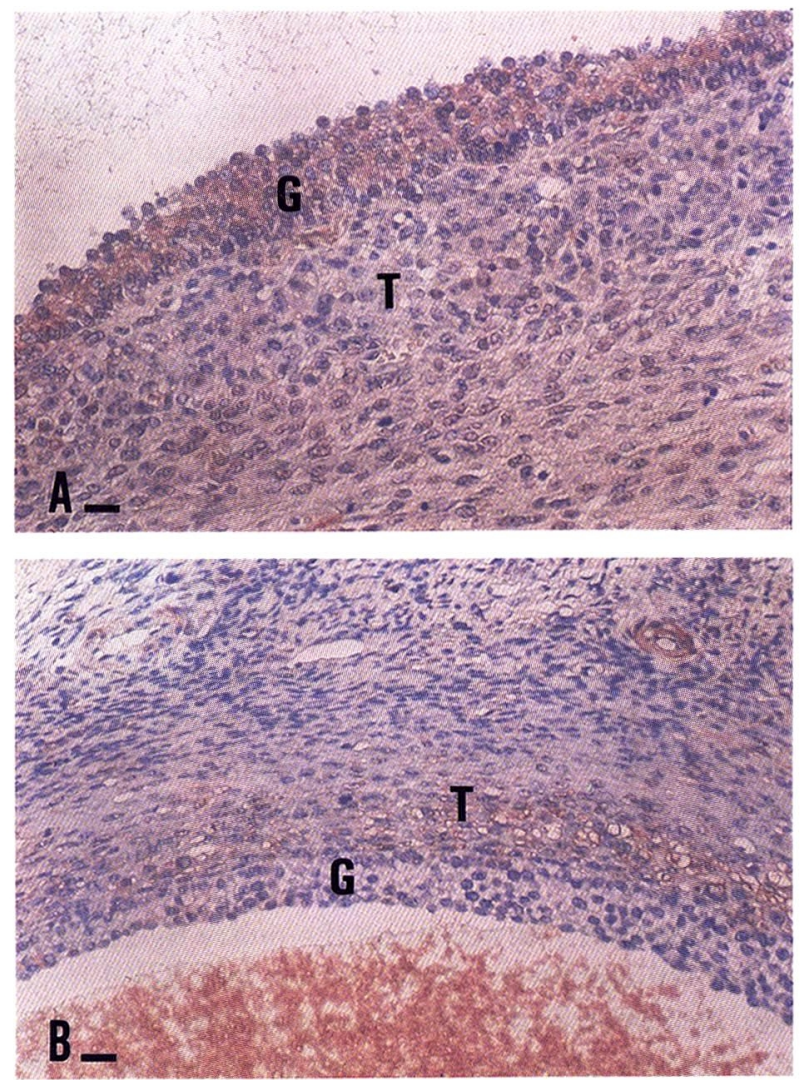

Fig. 8. Immunohistochemical localization of IGFBP-4 in antral follicles from a PCOS patient without hyperinsulinemia (A) and from a PCOS patient with hyperinsulinemia (B). In antral follicles from a PCOS patient without hyperinsulinemia, IGFBP-4 immunostaining was more prominent in the granulosa cells than in the theca cells, whereas in antral follicles from a PCOS patient with hyperinsulinemia, IGFBP-4 immunostaining was more prominent in the theca cells relative to that in the granulosa cells. G, granulosa; $T$, theca. Bar represents $10 \mu \mathrm{m}$. Original magnification, $\times 200$.

served the immunolocalization of IGF-I in the oocyte of primordial and growing follicles (Maruo T, unpublished data), an IGF-I - IGFBP-4 system may exist in the oocyte throughout follicular development. Unlike the expression of IGFBP-4 in the oocyte, there was a great difference between normal and PCOS ovaries in the expression of IGFBP-4 in the granulosa and theca cells. In normal ovaries, IGFBP-4 expression was negligible in the granulosa cells of preantral and antral follicles, while in atretic follicles within normal ovaries IGFBP-4 expression was abundant in the granulosa and theca cells. In contrast to this, in PCOS ovaries IGFBP-4 expression was prominant in the
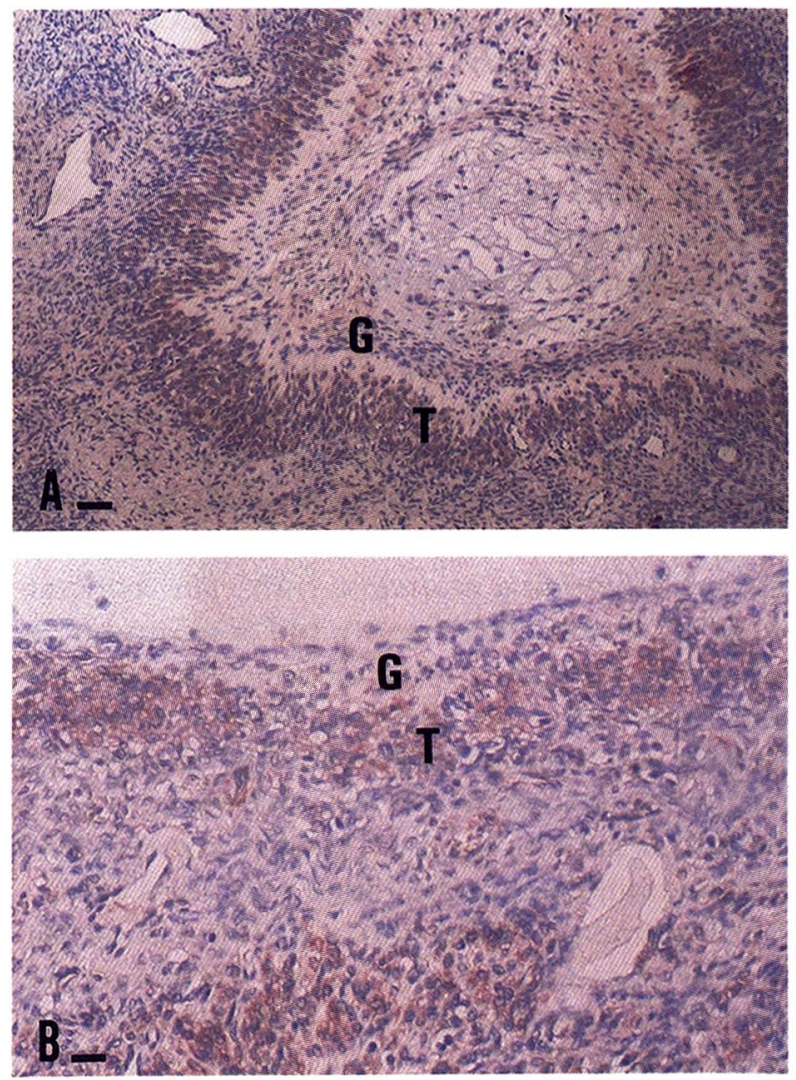

Fig. 9. Immunohistochemical localization of IGFBP-4 in atretic follicles from a PCOS patient without hyperinsulinemia (A) and from a PCOS patient with hyperinsulinemia (B). Prominent immunostaining for IGFBP-4 was apparent in the theca cells, regardless of the association of hyperinsulinemia. G, granulosa; $\mathrm{T}$, theca. Bar represents $10 \mu \mathrm{m}$. Original magnification, $\times 200$.

granulosa cells even in the preantral stage of follicle development. Furthermore, in antral follicles within PCOS ovaries the pattern of IGFBP-4 expression in the follicular compartment was greatly affected by the presence or absence of an association with hyperinsulinemia. In antral follicles from PCOS women without hyperinsulinemia, abundant expression of IGFBP-4 persisted in the granulosa cells of the antral follicles, whereas in PCOS ovaries from women with hyperinsulinemia IGFBP-4 expression was negligible in the granulosa cells, but abundant in the theca cells of the antral follicles. It is not clear why the pattern of IGFBP-4 expression in antral follicles of PCOS ovaries differs depending on the presence or absence of hyperinsulinemia. Nevertheless, the high abundance of IGFBP-4 in the follicular compartment of 
preantral and antral follicles within PCOS ovaries is very different from the pattern of expression of IGFBP-4 within normal ovaries. In normal human ovaries no appreciable expression of IGFBP-4 was noted in either the granulosa cells or the theca cells of the preantral and antral follicles. Only in the lutein cells of corpora lutea as well as the granulosa and theca cells of atretic follicles, IGFBP-4 expression was abundant. It should be noted that atresia of antral follicles can be characterized by the following histological changes. The early stage of atresia is characterized by a small number of granulosa cells with pyknotic nuclei and a reduction in proliferating granulosa cells. The moderate stage of atresia shows many pyknotic granulosa cells, very little thymidine incorporation and few cells in mitosis. The advanced stage is characterized by a reduction in the number of granulosa cells, none of them in mitosis, and the collapse of the follicle [19]. In contrast, healthy antral follicles contain numerous proliferating granulosa cells.

The abundant expression of IGFBP- 4 in the theca cells of atretic follicles within normal ovaries resembled the expression of IGFBP-4 in atretic follicles within PCOS ovaries. Actually, IGFBP-4 seems to be selectively expressed in the granulosa and theca cells in preantral and antral follicles of PCOS ovaries and in atretic follicles of normal ovaries. This is consistent with the reports of Cataldo et al. [26] and San Roman et al. [27] who noted that IGFBP-4 is present in greater amounts in FF in PCOS follicles and atretic follicles of normal cycling women relative to that in mature follicles. Furthermore, in the same context, Erickson et al. [17] have reported that in the rat IGFBP-4 mRNA is selectively expressed in corpora lutea and atretic follicles in the various stages of follicle development. Consistent with this report, abundant expression of IGFBP-4 in the lutein cells of corpora lutea was also noted in the present study. On the other hand, El-Roeiy et al. [30] reported that IGFBP-4 and -5 mRNAs and proteins were seen in all cell layers in all follicles examined and that the cellular distribution of IGFBP mRNA and protein in PCOS follicles was similar to that in small antral follicles of normal ovaries, but remarkable differences were found in dominant follicles. The disparity is difficult to explain, but it may be related to our use of an IGFBP-4 antibody which was preadsorbed with IGFBP-2 to abolish a minor cross reactivity to IGFBP-2 or may be related to the func- tional status of small antral follicles (healthy $v s$. atretic) examined.

On the basis of the present findings, one might expect that locally produced IGFBP-4 could sequester IGF-I in the microenvironment and send a follicle along the pathway of atresia, because IGFBP-4 binds IGF-I, rendering it inactive. In this connection, there is a growing body of evidence that luteal regression and follicular atresia occur by apoptosis $[19,31]$. This is consistent with the finding of abundant expression of IGFBP-4, a strong inhibitor of IGF action, in corpora lutea and atretic follicles of normal ovaries, since it is known that follicle selection is accompanied by the synthesis of IGF-I in the granulosa cells [32] and that IGF-I is capable of suppressing apoptosis in cultured preovulatory follicles [33]. It is therefore likely that the binding of IGFBP-4 to IGF-I in granulosa cells leads to decreases in the bioavailability of IGF-I and prevents the interaction of IGF-I with its receptor.

IGF-I initiates its action on the ovary by binding to its own receptors. Both insulin and IGF-I have been demonstrated to act synergistically with FSH to stimulate aromatase activity in granulosa cells and with $\mathrm{LH}$ to stimulate androgen production by stromal cells [34-37]. We have noted that insulin competes for IGF-I binding to granulosa cells with about 100 fold less activity relative to IGF-I [3]. It is therefore possible that the action of high concentrations of insulin could be mediated via IGF-I receptors demonstrable on granulosa cells. In this context, we have previously shown that in PCOS ovaries from women with hyperinsulinemia IGF-I receptor expression increased in the thecal stromal cells but decreased in the granulosa cells compared to that in normal ovaries, whereas in PCOS ovaries from women without hyperinsulinemia IGF-I receptor expression was negligible in the granulosa cells but sustained in the thecal stromal cells [38]. These findings have suggested that the defective expression in granulosa cells along with increased or persistent expression in thecal stromal cells of IGF-I receptors may be common in PCOS ovaries and contribute to the endocrine profiles of PCOS in which varying degrees of hyperandrogenism is a predominant feature.

In conclusion, IGF-I is a potent stimulator of FSH action in growing follicles. In light of the high affinity of IGFBP-4 for IGF-I, an increase in the expression of IGFBP-4 in the granulosa cells of pre- 
antral and small antral follicles of PCOS ovaries is likely to decrease the level of free IGF-I which is capable of activating the specific receptors for IGFI. The decrease in IGF-I-mediated stimulation of FSH action on the granulosa cells within preantral and antral follicles may impair the induction of aromatase activity, causing an androgenic microenvironment which is characteristic of atretic follicles. For this reason, the defect or impairment of FSH action on the granulosa cells of preantral and antral follicles caused by the increased IGFBP-4 expression may be at least partly responsible for the arrest of follicular maturation in the early antral stage of follicle development which is characteristic of PCOS ovaries.

\section{Acknowledgements}

This work was supported in part by Grants-inAid for Scientific Research 05454451 and 07457388 from the Japanese Ministry of Education, Science and Culture, and by the International Committee of the Population Council, New York. X. Peng was supported by Sasakawa Medical Research Fellowship and Morinaga-Sakamoto Research Fund for Population Sciences.

\section{References}

1. Giudice LC (1992) Insulin-like growth factors and eovarian follicular development. Endocr Rev 13: 641669.

2. Adashi EY, Resnick CE, D'Ercole AJ, Svoboda ME, Van Wyk JJ (1985) Insulin-like growth factors as intraovarian regulators of granulosa cell growth and function. Endocr Rev 6: 400-420.

3. Maruo T, Hayashi M, Matsuo H, Ueda Y, Morikawa H, Mochizuki M (1988) Comparison of the facilitative roles of insulin and insulin-like growth factor I in the functional differentiation of granulosa cells: In vitro studies with the porcine model. Acta Endocrinol (Copenh) 117: 230-240.

4. Adashi EY, Resnick CE, Hernandes ER, Svoboda ME, Van Wyk JJ (1989) The potential relevance of insulin-like growth factor-I to ovarian physiology: From basic science to clinical application. Semin Reprod Endocrinol 7: 94-100.

5. Shimasaki S, Ling N (1991) Identification and molecular characterization of insulin-like growth binding proteins (IGFBP1-6). Prog Growth Factor Res 3: 243-266.

6. Shimasaki S, Shimonaka M, Zhang HP, Ling N (1991) Identification of five different insulin-like growth factor binding proteins (IGFBPs) from adult rat serum and molecular cloning of novel IGFBP-4 in rat and human. J Biol Chem 266: 10646-10653.

7. Ritvos O, Ranta T, Jalkanen J, Suikkari A-M, Voutilainen R, Bohn H, Rutanen E-M (1988) Insulin-like growth factor (IGF) binding protein from human decidua inhibits the binding and biological action of IGF-I in cultured choriocarcinoma cells. Endocrinology 122: 2150.

8. Pekone F, Suikkari A-M, Makinen T, Rutanen EM (1988) Different insulin-like growth factor binding species in human placenta and decidua. J Clin En- docrinol Metab 67: 1250.

9. Rutanen EM, Pekonen F, Makinen T (1988) Soluble $34 \mathrm{~K}$ binding protein inhibits the binding of insulinlike growth factor I to its cell receptors in human secretory phase endometrium: Evidence for autocrine/paracrine regulation of growth factor action. J Clin Endocrinol Metab 66: 173.

10. Elgin RG, Busby WH, Clemmons DR (1987) An insulin-like growth factor (IGF) binding protein enhances the biologic response to IGF-I. Proc Natl Acad Sci USA 84: 3254.

11. Clemmons DR, Gradner LI (1990) A factor contained in plasma is required for IGF binding protein-1 to potentiate the effect of IGF-I on smooth muscle cell DNA synthesis. J Cell Physiol 145: 129.

12. Ui M, Shimonaka M, Shimasaki S, Ling N (1989) An insulin-like growth factor-binding protein in ovarian folicular fluid blocks follicle-stimulating hormone-stimulated steriod production by ovarian granulosa cells. Endocrinology 125: 912-916.

13. Bicsak TA, Ling N, DePaolo LV (1991) Ovarian intrabursal administration of insulin-like growth factor-binding protein inhibits follicle rupture in gonadotropine-treated immature female rats. Biol Reprod 44: 599-603.

14. Bicsak TA, Motoyuki S, Malkowski M, Ling N (1990) Insulin-like growth factor-binding protein (IGFBP) inhibition of granulosa cell function: Effect on cyclic adenosine 3',5'-monophosphate, deoxyribonucleic acid synthesis, and comparison with the effect of an IGF-I antibody. Endocrinology 126: 2184 2189.

15. Adashi EY, Resnic CE, Ricciarelli E, Hurwitz A, Kokia E, Tedeschi C, Botero L, Hernandez ER, Rosenfeld RG, Carlsson-Skwirut C, Fancis GL (1992) Granulosa cell-derived insulin-like growth factor 
(IGF) binding proteins are inhibitory to IGF-I hormonal action: Evidence derived from the use of a truncated IGF-I analogue. J Clin Invest 90: 15931599.

16. Mason HD, Willis D, Holly JM, Cwyfan-Hughes SC, Seppala M, Franks S (1992) Inhibitory effects of insulin-like growth factor-binding proteins on steroidogenesis by human granulosa cells in culture. Mol Cell Endocrinol 89: R1-R4.

17. Nakatani A, Shimasaki S, Erickson GF, Ling N (1991) Tissue specific expression of four insulinlike growth factor binding proteins (1, 2, 3 and 4) in the rat ovary. Endocrinology 129: 1521-1529.

18. Erickson GF, Nakatai A, Ling $N$ and Shimasaki $S$ (1992) Cyclic changes in insulin-like growth factorbinding protein- 4 messenger ribonucleic acid in the rat ovary. Endocrinology 130: 625-636.

19. Hsueh AJW, Billig H, Tsafriri A (1994) Ovarian follicle atresia: A hormonally controlled apoptotic process. Endocr Rev 15: 707-723.

20. Chang RJ, Nakamura RM, Judd HL, Kaplan SA (1983) Insulin resistance in nonobese patients with polycystic ovarian disease. J Clin Endocrinol Metab 57: 356-59.

21. Barbieri RL, Smith S, Ryan KJ (1988) The role of hyperinsulinemia in the pathogenesis of ovarian hyperandrogenism. Fertil Steril 50: 197-212.

22. Poretsky L (1991) On the paradox of insulin-induced hyperandrogenic in insulin-resistant states. Endocr Rev 12: 3-13.

23. Burghen GA, Givens JR, Kitabachi AE (1980) Correlation of hyperandrogenism with hyperinsulinemia in polycystic ovarian disease. J Clin Endocrinol Metab 50: 113-116.

24. Nader S (1991) Polycystic ovary syndrome and the androgen-insulin connection. Am J Obstec Gynecol 165: 346-348.

25. Monget P, Monniaux D, Pisselet C, Durand P (1993) Changes in insulin-like growth factor-I (IGF-I), IGFII, and their binding proteins during growth and atresia of ovine ovarian follicles. Endocrinology 132: 1438-1446.

26. Cataldo NA, Giudice LC (1992) Follicular fluid insulin-like growth binding protein profiles in polycystic ovary syndrom. J Clin Endocrinol Metab 74: 695-696.

27. San Roman GA, Magoffin GA (1992) Insulin-like growth factor binding proteins in ovarian follicles from women with polycystic ovarian disease: Cellular source and levels in follicular fluid. J Clin Endocrinol Metab 75: 1010-1016.

28. Holly JMP, Eden JA, Alaghband-Zadeh J (1990) Insulin-like growth factor binding protein profiles in follicular fluid from normal dominant and cohort follicles, polycystic and multicystic ovaries. Clin Endocrinol (Oxf) 33: 53-64.

29. Maruo T, Mochiziki M (1987) Immunohistochemical localization of epidermal growth factor receptor and myc oncogene product in human placeta: Implication for trophoblast proliferation and differentiation. Am J Obstec Genecol 156: 721-722.

30. El-Roeiy A, Chen X, Roberts VJ, Shimasaki S, Ling N, Leroith D, Roberts CT, Yen SSC (1994) Expression of the genes encoding the insulin-like growth factors (IGF-I and IGF-II), the IGF and insulin receptors, and IGF-binding proteins-1-6 and the localization of their gene products in normal and polycystic ovary syndrome ovaries. J Clin Endocrinol Metab 78: 1488-1496.

31. Tilly JL, Kowalski KI, Johnson AL, Hsueh AJW (1991) Involvement of apoptosis in ovarian follicular atresia and postovulatory regression. Endocrinology 129: 2799-2801.

32. Oliver JE, Altman TJ, Powell JF, Wilson CA, Clayton RN (1989) Insulin-like growth factor I gene expression in the rat ovary is confined to the granulosa cells of developing follicles. Endocrinology 124: 26712679.

33. Chun Sy, Billig H, Tilly J, Furuta I, Tsafriri A, Hsueh AJW (1994) Gonadotropin suppression of apoptosis in cultured preovulatory follicles: Mediatory role of endogenous insulin-like growth factor-I. Endocirnology 135: 1845-1853.

34. Garzo VG, Dorrington JH (1984) Aromatase activity in human granulosa cells during follicular development and the modulation by FSH and insulin. Am J Obstet Gynecol 148: 657-662.

35. Erickson GF, Garzo VG, Magoffin DA (1989) Insulin-like growth factor I (IGF-I) regulates aromatase activity in human granulosa and granulosa luteal cells. J Clin Endocrinol Metab 69: 716-724.

36. Barbieri RL, Makris A, Randall RW, Daniels G, Kistner RW, Ryan KJ (1986) Insulin stimulates androgen accumulation in incubation of ovarian stroma obtained from women with hyperandrogenism. J Clin Endocrinol Metab 62: 904-910.

37. Hernandez RE, Resnick CE, Svoloda EM, Van Wyk JJ (1988) Somatomedin-C/insulin-like growth factor I as an enhancer of androgen biosynthesis by cultured rat ovarian cells. Endocrinology 122: 16031612.

38. Samoto T, maruo T, Matso H, Katayama K, Barnea EB, Mochizuki M (1993) Altered expression of insulin and insulin-like growth factor-I receptors in follicular and stromal compartments of polycystic ovaries. Endocr Journal 40: 413-424. 